\title{
LEADERSHIP IN SURGICAL SCIENCE: LITERATURE REVIEW
}

\author{
Chaula Luthfia Sukasah ${ }^{1}$, Indri Aulia1 ${ }^{*}$, T. Fadli Nazwan Sani² \\ 1. Universitas Indonesia, Departement of Surgery, Division of Plastic Reconstructive Aesthetic Surgery, RSUPN Cipto Mangunkusumo, \\ Jakarta, Indonesia \\ 2. General Practioner; Intern Participant in Plastic Reconstructive Aesthetic Surgery, RSUPN Cipto Mangunkusumo, Jakarta, Indonesia
}

\begin{abstract}
Background : A Surgeon should have good leadership. Leadership plays an important role in improving health services. Leadership can shape a better future.

Method : A literature search was conducted in November 2019. Related keywords were applied to Pubmed, Medline, and SCOPUS for studies published in the last five years. Relevant research is taken to be used as the discussion material.

Result : The key to surgical leadership is collaboration and cooperation, humanism and mentorship, and operational efficiency.

Conclusion: Effective leadership in a surgical team has the following characteristics: (1) Defines the role of a leader clearly, especially in critical situations; (2) Leadership style that suits the clinical situation; (3) Clear directions to team members; (4) Consistently seeking input from team members; (5) Involving members in decision making.

Keywords: leadership, surgeon

Latar Belakang: Kepemimpinan dalam diri seorang ahli bedah mutlak dimiliki. Kepemimpinan berperan penting dalam membawa pelayanan kesehatan menjadi lebih baik. Kepemimpinan dapat membentuk masa depan yang lebih baik.

Metodologi: Literatur dikumpulkan dari Pubmed, Medline, dan SCOPUS atas artikel yang sudah dipublikasi sejak tahun 2014. Penelitian yang relevan diambil untuk dijadikan bahan diskusi.

Hasil: Kunci kepemimpinan bedah memiliki 3 prinsip utama: kolaborasi dan kooperatifitas, humanisme dan mentorship, serta efesiensi operasional.

Kesimpulan: Kepemimpinan yang efektif dalam tim bedah memiliki karakter sebagai berikut: (1) Secara jelas mendefinisikan peran seorang pemimpin, terutama dalam situasi kritis; (2) Gaya kepemimpinan yang sesuai dengan situasi klinis; (3) Arahan yang jelas kepada anggota tim; (4) Secara konsisten mencari masukan dari anggota tim; (5) Melibatkan anggota dalam pengambilan keputusan.

Keywords: leadership, surgeon, medical education
\end{abstract}




\section{INTRODUCTION}

There is a lot of leader position for doctors in a clinical setting. This leadership skill should be trained since preclinical education and applied to the clinical setting. This skill could be developed from various training. Formal surgery education provides specific insights, experiences, and expertise, while leadership is obtained from daily clinical practice. A doctor's leadership could bring a better health service that affects the quality of health services to patients. ${ }^{1}$

Leadership in surgery must be futureoriented. Leadership aims to shape a better future by conveying ideas in a cooperative manner and always achieve more. Leaders create the future by: (1) Developing an interesting vision; (2) communicating views in the future; (3) Encouraging others to pursue their achievements in the future; (4) Demonstrate a consistent commitment to the vision to be achieved. ${ }^{2}$

In the United States, the Accreditation Council for Graduate Medical Education (ACGME) has established six core competencies, including patient care, medical knowledge, practice-based learning, communication skills and interpersonal relationships, professionalism, and systems-based practice. Each competency at the level contains the principle of leadership. ${ }^{3}$

\section{METHOD}

Literature was collected from Pubmed, Medline, and SCOPUS on articles that have been published since 2014. Relevant studies were reviewed in this paper. Key terms used in this article are leadership, surgeon, and medical education. The literature searched randomized controlled trials, observational studies, case reports, clinical reviews, and editor reviews. The bibliography of each article was reviewed for relevant references. The journal was limited to articles which written in English with the topic of surgeon leadership.

\section{REVOLUTIONARY LEADERSHIP SURGEON}

The field of surgery has evolved, and surgeons need the capabilities of modern leadership skills, as well as the ability to master medical knowledge and surgical techniques. Historically, surgeons take full responsibility for their patients and direct actions in the operating room with absolute authority, using the command and control leadership style. Modern surgical practice has now evolved from single provider-based care to a teambased approach, which requires collaborative leadership skills. ${ }^{3,4}$
A surgical procedure is a collaboration between surgeons, anesthesiologists, internists, radiologists, pathologists, radiation oncologists, nurses, pharmacists, social workers, therapists, hospital staff, and administrators. As a team leader, surgeons are able to improve the outcome of health services to patients, reduce medical errors, and increase patient satisfaction through their leadership of a multidisciplinary team. Thus, in the modern health system, a lot of surgery education program provides leadership education. 3,4 .

The surgery department recognizes the need for improving leadership among doctors. Resident in Surgery states that leadership skills are important, but they seemed to be "incompetent" or "slightly competent" in this skill. A small percentage of Surgery residency program have implemented a formal curriculum focusing on leadership. Currently, it is important that all Surgery residency program teach this important skill to their students. $3-5$

A number of surgeons identified several important factors that influence leadership success, including mastering vision, communication, management, emotional intelligence, team building, business skills, selfmanagement, and systematic thinking. Emotional intelligence is a fundamental ability for the success of a surgeon regardless of their medical knowledge. Important elements in leadership are: leadership style, team building, innovation, strategy, financial management, marketing, operational management, and applicable health regulations. ${ }^{2-3}$

In reality, good training can be assessed from its outputs. Training is only a tool to create a cultural innovation that develops in a study program.

Disclosure: The authors have no financial interest to disclose. 


\section{KEY TO LEADERSHIP SURGEONS}

The keys to surgical leadership are collaboration and cooperation, humanism and mentorship, and operational efficiency. In the collaboration and cooperation, the emphasized value is a collaboration with others and institutional leadership to achieve the mission; regular attendance and advocacy at organizational meetings and fostering good relations and trust in subordinates as a substitute for representing the leader. The principle of humanism and mentorship emphasizes that leaders must act as surgeons and perform surgeries, understand the goals and interests of each staff, set clear and consistent targets and objectives, provide non-financial rewards to motivate teaching staff, and leaders in a group or community as a mentor partner.

The third principle is operational efficiency. It contains recruitment and development of staff, creating a map of staff strength to produce a "triple threat" team, understanding and integrating institutional priorities, changes occur because of evolution rather than revolution, clear and specific feedback for quality improvement, understanding the emergence of capitation and centers Multidisciplinary health services as a key to excellence and new economic strength, and recognize the potential transition from the surgical department that will require increased cost efficiency. ${ }^{6}$

\section{CONCLUSION}

Surgeons are leaders who are ready to take on various leadership opportunities in health services. This position provides an opportunity to work more than the patient's management only. Some people are born with natural leadership skills, while others have to learn to develop these abilities. The process of leadership ability must be trained from the first year as a medical student up to residency program. ACS has initiated "Residents as Teachers and Leaders". This training aims to help residents master critical and nonclinical skills related to lead groups and teach them. A balance between the role of the clinician and the career in the administrative field must be achieved. ${ }^{1}$

Effective leadership in a surgical team has the following characteristics: (1) Clearly defines the role of a leader, especially in critical situations; (2) Leadership style that suits the clinical situation; (3) Clear directions to team members; (4) Consistently seeking input from team members; (5) Involving members in decision making.7 Despite the career goals of a surgeon, his role in building a team is one of the characteristics of a successful leader. ${ }^{1}$

\section{Corresponding author : \\ Indri Aulia}

Cipto Mangunkusumo General National Hospital drindriaulia@gmail.com

\section{REFERENCES}

1. Maykel JA. Leadership in surgery. Clinics in Colon and Rectal Surgery. 2013;26(4): 254-258.

2. Mulholland MW. Leadership in surgery. In: Kribber MR, Chen H (Eds.). Success in academic surgery. Switzerland: Springer International Publishing; 2015.

3. Hill AL. Wu J. Girgis MD, Hsu D, Tillou A; Macho J. et al. Fundamental principles of leadership training in surgery. In: Brunicardi FC. Andersen DK. Billiar TR. Dunn DL. Hunter JG, Matthews JB. Et al. Schwartz's principles of surgery. Tenth Edition. New York: McGraw-Hill Education; 2011.

4. Prabhakaran S, Economopoulos KP, Grabo DJ, Sakran JV. Surgical leadership across generations. [Features]. American College of Surgeons; 2012.

5. Itani KMF, Liscum K, Brunicardi C. Physician is a new mandate in surgical training. The American Journal of Surgery. 2004; 187:328-331.

6. Rosengart TK, Kent KC, Bland KI, Britt LD, Eberlein TJ, Gewertz BL. Et al. Key tenets of effective surgery leadership: perspectives from the Society of surgical chairs mentorship sessions. JAMA Surg. 2016;151(8):768-770.

7. Supports Good Surgical Practice. Surgical leadership: a guide to best practice. London: The Royal College of Surgeons of England; 2014 